\title{
The Important Role of TMPRSS2 Gene in Covid-19 and Prostate Cancer: In Silico Approach
}

\author{
Arif Kalkanli ${ }^{1}$ \\ https://orcid.org/0000-0001-6509-4720 \\ Duygu Kirkik ${ }^{2}$ \\ https://orcid.org/0000-0003-1417-6915 \\ Emre Bostanci ${ }^{3}$ \\ https://orcid.org/0000-0002-0462-3171 \\ Sevgi Kalkanli Tas ${ }^{*}$ \\ https://orcid.org/0000-0001-5288-6040 \\ ${ }^{1}$ Taksim Education and Research Hospital, Department of Urology Istanbul, Turkey; ${ }^{2}$ University of Health Sciences, \\ Hamidiye Medicine Faculty, Department of Medical Biology, Istanbul, Turkey; ${ }^{3}$ Abant Izzet Baysal University, Medicine \\ Faculty, Department of Urology, Bolu, Turkey; ${ }^{4}$ University of Health Sciences, Hamidiye International Medicine Faculty, \\ Department of Immunology, Istanbul, Turkey.
}

Editor-in-Chief: Alexandre Rasi Aoki

Associate Editor: Daniel Fernandes

Received: 2020.12.14; Accepted: 2021.05.29.

${ }^{*}$ Correspondence: skalkanlitas@gmail.com; Tel: +90 5327259336 (S. K. T.).

\section{HIGHLIGHTS}

- The main characteristic of SARS-CoV, MERS-CoV and SARS-CoV-2 is that air passes through the upper respiratory tract

- $\quad$ The tissue of the upper respiratory tract can express both ACE2 and TMPRSS2.

- $\quad A R$ is abundantly expressed in lungs.

- TMPRSS2, ACE2, and AR connection explains why high expression of AR gene is present in the male lung.

Abstract: Some studies have discovered a connection between prostate cancer and COVID-19. In this study, we evaluated the link between prostate cancer and COVID-19, contributing to elucidate the connection between TMPRSS2 and ACE2. We discovered 209 number of variants in TMPRSS2 gene, and 110 variants represent EA populations and 99 of them represent AA populations. Moreover, we found 23 suspected missense and 3 unknown variants. Then, linked genes to TMPRSS2 and ACE2 were found in our study. We investigated the expression level of TMPRSS2 and the results showed that it was very high in the prostate, colon, lung, kidney, and saliva-secreting gland. Also, the important role of the $A R$ gene was revealed in addition to other oncogenes and tumor suppressor genes for prostate cancer by KEGG Pathway analysis. In conclusion, these results can highlight several molecular mechanisms of SARS-CoV-2, and also TMPRSS2, $A C E 2$, and $A R$ connection explains the high expression level of $A R$ gene found in the male lung.

Keywords: COVID-19; ACE2; Prostate cancer; AR; TMPRSS2. 


\section{INTRODUCTION}

Prostate cancer is one of the most common types of cancer in men that cause death all over the world $[1,2]$. According to the American Cancer Society, the number of newly detected prostate cancer patients has increased by approximately 30\% since 2020 and researchers have thought that there will be more than 34,000 prostate cancer-linked deaths in this year [3]. Although the cause of prostate cancer is not known exactly, advanced age, ethnicity, genetic factors, and family history are thought to be the leading factors for prostate cancer [4,5]. According to the latest studies, the TMPRSS2 gene is identified as a prostate-specific and androgen-responsive gene that encodes transmembrane serine protease 2 and it plays an important role in the development of prostate cancer, as it is expressed in large amounts on prostate cancer and contains androgen response elements [6,7]. TMPRSS2 is known to be expressed on the luminal side of the prostate epithelium, and when the expression of the TMPRSS2 on the normal tissue is compared with the cancerous prostate epithelium, the cancerous tissue of the prostate shows higher expression than the normal tissue [8]. TMPRSS2, a component of the serine protease family, is participating in a range of pathophysiological events, as well as enabling the entrance of viruses such as SARS-CoV-2 (severe acute respiratory syndrome coronavirus 2) through cleaving and stimulating viral envelope glycoproteins, or proteolytically cleaving the ACE2 (angiotensin-converting enzyme 2) receptor for viral entry. [8]. Many studies have shown that in vitro activation of viral spikes might be mediated by other proteases such as TMPRSS4, TMPRSS11A, TMPRSS11D, TMPRSS11E1, and TMPRSS2 activity, and it is considered to have a role in cell entry and viral pathogenesis [9]. Although the presence of TMPRSS-ERG fusion gene (transmembrane protease serine2:v-ets erythroblastosis virus E26 oncogene homolog) has been detected in $40-80 \%$ of human prostate cancer, its role is not defined clearly [10]. Tomlins and his colleagues [11] identified that overexpression of $E R G$ has been seen in $55 \%$ of prostate cancer cases. $E R G$ is an oncogene that plays a regulator role in cell proliferation, angiogenesis, inflammation, and apoptosis [12]. The TMPRSS2:ERG gene fusion is a genomic alteration in human malignancy [13]. By interrupting the androgen receptor (AR) lineage-specific differentiation pathway of the prostate, TMPRSS2:ERG fusion might promote carcinogenesis. The gene fusion can suppress $A R$ signaling, resulting in a restrictive pressure that contributes to recurring cancers with an increase in AR [14].

As reported by the study indicating ACE2 and TMPRSS2 expression levels and their distribution across cell types in lung tissue and cells derived from subsegmental bronchial branches by single nuclei and singlecell RNA sequencing, respectively, and this study has revealed that TMPRSS2 is abundantly expressed in lung tissue and cells derived from subsegmental bronchial branches but ACE2 is highly expressed in a transient secretory cell type [9]. Another study has been evaluated the effectiveness of two different inhibitors of TMPRSS2 which are nafamostat and camostat in the treatment of COVID-19 [15]. There is an interesting relationship between the TMPRSS2 gene and the COVID-19 which has affected many people recently. It is a fact that TMPRSS2 leading viral entry within the lung cells promotes the infection by other viruses. A study has demonstrated that TMPRSS2 knockout mice infected with the H1N1 influenza virus did not cause serious respiratory diseases compared to wild-type mice [16].

According to the World Health Organization Coronavirus disease 2019 (COVID-19) Weekly Report - 11 May 2021, the total number of confirmed cases reached approximately 157 million, with over 3 million deaths in the world [17]. Scientists have continued to research why the most severe course of the disease is associated with older age in males. Some studies have shown that the relationship between high androgen levels and TMPRSS2 expression in prostate cancer may also be related to COVID-19 in which the prevalence is found to be higher in men $[18,19]$. In this study, we investigated the link between prostate cancer and COVID-19, contributing to elucidate the relationship between TMPRSS2 and ACE2.

\section{MATERIAL AND METHODS}

\section{Finding of the TMPRSS2 gene dataset collection}

Databases of Online Mendelian Inheritance in Man (OMIM) [20] and Entrez Gene on National Center for Biological Information (NCBI) [21] were used to obtained information on TMPRSS2. The Single Nucleotide Polymorphism (SNPs) information (Protein accession number and SNP ID) of the TMPRSS2 gene was acquired from the NCBI dbSNP [22], and SWISS Prot databases [23]. 


\section{Analysis of Functional and Physical Genes Similar to ACE2 and TMPRSS2}

STRING database was used to show the protein associations network. Moreover, GeneMania was employed to exhibit the relationship between the known gene and other genes. Analysis of functional and physical similar genes was found by the GeneMania program to understand the relationship between ACE2 and TMPRSS. Results obtained by this database was verified with STRING database [24].

\section{Finding of Suspicious SNPs in TMPRSS2 and Prediction of the Expression level of TMPRSS2 gene}

Exome Variant Server (EVS) was used to detect the number of variations of TMPRSS2 gene and its frequency to find suspicious SNPs. In this study, probable damaging SNPs were identified for TMPRSS2 gene and allele frequency were calculated with this database [25]. Determining of nonsynonymous variants was found by SIFT algorithm [26] and defining damaging effects of the nonsynonymous variant was found by Polyphen-2. Then all data was verified with each other [27]. Analyzing the expression level of a gene is important and it establishes a link between genes and diseases. The expression level of the TMPRSS2 gene was found by UniProt, and BioXpress databases. Then, gene expression, exon expression, and junction expression of the gene were verified with GTex portal, and Ensembl Genome Browser [28-30].

\section{Pathway and Diseases Analysis of TMPRSS2}

KEGG is a database which is used to find the methodical searching of gene functions. KEGG database was employed to process of mapping of the TMPRSS2 gene and we have shown the importance of TMPRSS2 gene in prostate cancer. The database is correlated to genomic information with other advanced classified functional parts [30]. Our results were compared to each other and validation was done by STRING. Additionally, diseases and TMPRSS2 gene association was found by the DISEASES resource database [32].

\section{RESULTS}

GeneMANIA helps to investigate many large, biological datasets to discover associated genes. This program analyzes protein-protein, protein-DNA and genetic interactions, pathways, reactions, gene and protein expression data, protein domains and phenotypic screening profiles. We found that TMPRSS2 interacted with ACE2, ACE, AGT, PDE9A, SLC44A4, RASEF, TRPM4, SLC10A2, SLC37A1, and CAT genes shown in Figure 1. Secondly, we searched genetic variants identified in patients using a chromosome position by Exome Variant Server for and we found 209 variants in the TMPRSS2 gene, and 110 variants represent EA populations and 99 of them represent AA populations. Moreover, we found 23 suspected missense and 3 unknown variants indicated in Table 1. Molecular interactions, reactions and relations were mapped for TMPRSS2 and other connected genes by KEGG pathway analysis. The mechanism of the $A R$ gene in connection with TMPRSS2 was highlighted in the context of reported effects on prostate cancer demonstrated in Figure 2. Analyzing the expression level of the TMPRSS gene is significant and we have shown the expression level of TMPRSS2 in different tissues in Figure 3 and Figure 4 by UniProt, BioXpress databases, and Expression Atlas. Then, we analyzed the relationship between TMPRSS2 gene and diseases by DISEASES resource database in Table 2. According to our results, TMPRSS2 can play role in prostate cancer, COVID-19, carcinoma, breast cancer, middle east respiratory syndrome, severe acute respiratory syndrome, lung cancer, sarcoma, leukemia, influenza. 
Analysis of Functional and Physical Genes Similar to ACE2 and TMPRSS2

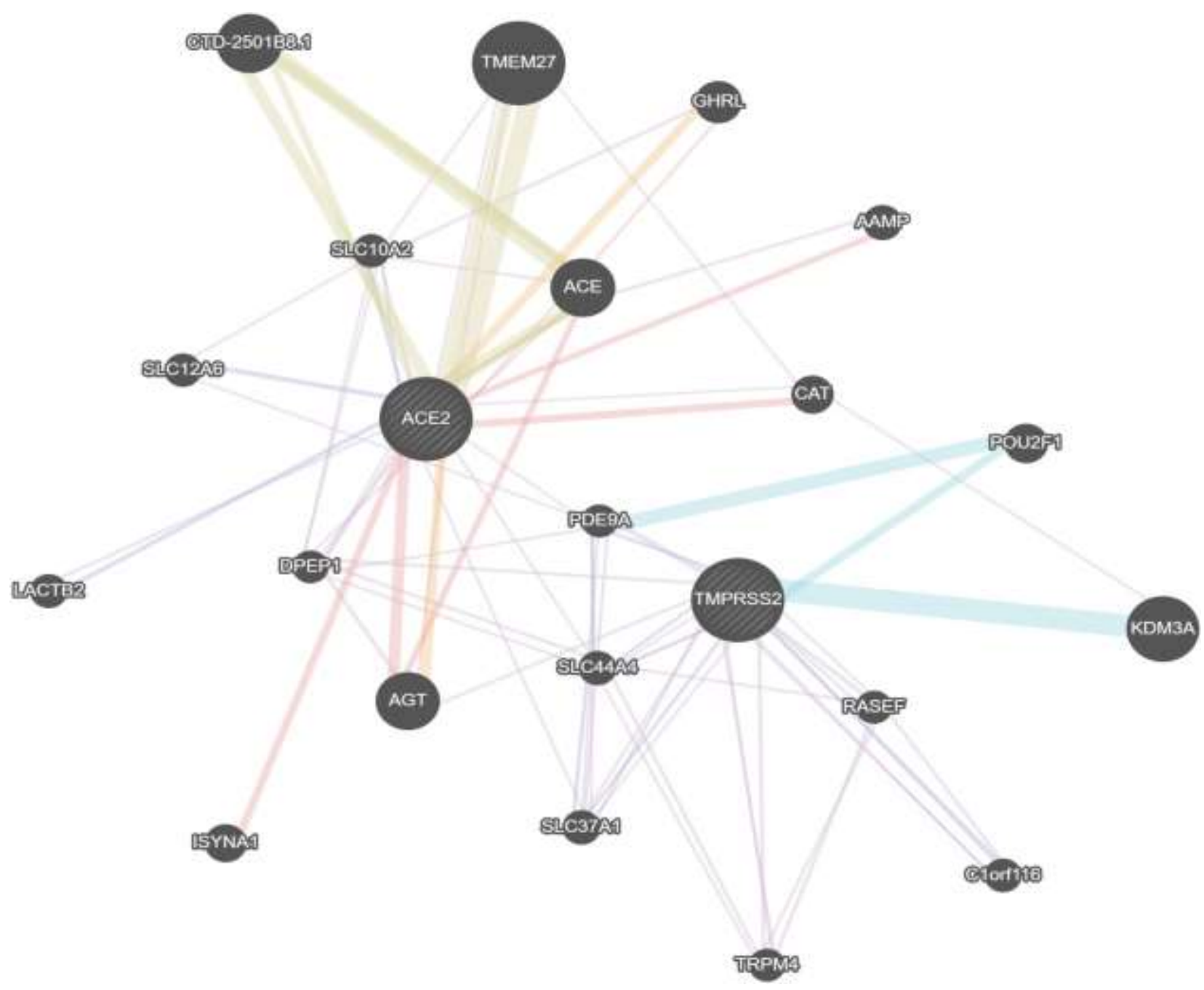

Figure 1. The figure obtained from the GeneMania database shows the relationship between TMPRSS2 and other genes. Co-expression (lilac), co-localization (blue), physical interaction (pink), and shared protein domains (brown) have been shown in different colors. 
Finding of Suspicious SNPs in TMPRSS2

Table 1. The predicted number of variations in TMPRSS2 was indicated and suspected SNPs detected on TMPRSS2 were listed in addition to genotypes, functions and PolyPhen2 scores to predict probable damages.

\begin{tabular}{|c|c|c|c|c|c|}
\hline rs ID & Alleles & EA Genotype & AA Genotype & $\begin{array}{c}\text { GVS } \\
\text { Function }\end{array}$ & $\begin{array}{c}\text { PolyPhen2 } \\
\text { (Class: Score) }\end{array}$ \\
\hline rs368268847 & $\mathrm{C}>\mathrm{A}$ & $\mathrm{A}=0 / \mathrm{C}=8600$ & $A=1 / C=4405$ & missense & $\begin{array}{l}\text { probably- } \\
\text { damaging:0.999 }\end{array}$ \\
\hline rs145171279 & $\mathrm{G}>\mathrm{C}$ & $C=1 / G=8599$ & $C=0 / G=4406$ & missense & $\begin{array}{l}\text { probably- } \\
\text { damaging:1.0 }\end{array}$ \\
\hline rs373952557 & $\mathrm{T}>\mathrm{G}$ & $G=1 / T=8597$ & $\mathrm{G}=0 / \mathrm{T}=4404$ & missense & $\begin{array}{l}\text { possibly- } \\
\text { damaging:0.692 }\end{array}$ \\
\hline rs370043174 & $\mathrm{T}>\mathrm{C}$ & $C=1 / T=8599$ & $\mathrm{C}=0 / \mathrm{T}=4404$ & missense & $\begin{array}{l}\text { probably- } \\
\text { damaging:0.964 }\end{array}$ \\
\hline rs144046631 & $\mathrm{T}>\mathrm{C}$ & $C=0 / T=8600$ & $\mathrm{C}=2 / \mathrm{T}=4402$ & missense & $\begin{array}{l}\text { probably- } \\
\text { damaging:0.997 }\end{array}$ \\
\hline rs146654734 & $G>C$ & $C=2 / G=8552$ & $C=0 / G=4354$ & missense & $\begin{array}{l}\text { probably- } \\
\text { damaging:0.998 }\end{array}$ \\
\hline rs372563970 & $\mathrm{C}>\mathrm{T}$ & $\mathrm{T}=0 / \mathrm{C}=8554$ & $\mathrm{~T}=1 / \mathrm{C}=4353$ & Missense & $\begin{array}{l}\text { probably- } \\
\text { damaging:0.999 }\end{array}$ \\
\hline rs 142446494 & $C>T$ & $\mathrm{~T}=2 / \mathrm{C}=8554$ & $\mathrm{~T}=0 / \mathrm{C}=4362$ & missense & $\begin{array}{l}\text { possibly- } \\
\text { damaging:0.64 }\end{array}$ \\
\hline rs140547429 & $C>T$ & $\mathrm{~T}=0 / \mathrm{C}=8560$ & $\mathrm{~T}=1 / \mathrm{C}=4351$ & missense & $\begin{array}{l}\text { possibly- } \\
\text { damaging:0.812 }\end{array}$ \\
\hline$\underline{\text { rs } 150445636}$ & $\mathrm{G}>\mathrm{A}$ & $A=1 / G=8561$ & $A=1 / G=4359$ & missense & $\begin{array}{l}\text { probably- } \\
\text { damaging:0.999 }\end{array}$ \\
\hline rs143049780 & $A>G$ & $G=1 / A=8557$ & $G=0 / A=4364$ & missense & $\begin{array}{l}\text { probably- } \\
\text { damaging:0.998 }\end{array}$ \\
\hline$\underline{\text { rs148049486 }}$ & $A>G$ & $G=1 / A=8599$ & $G=0 / A=4406$ & missense & $\begin{array}{l}\text { possibly- } \\
\text { damaging:0.82 }\end{array}$ \\
\hline rs 150554820 & $A>T$ & $T=2 / A=8598$ & $\mathrm{~T}=0 / \mathrm{A}=4406$ & missense & $\begin{array}{l}\text { possibly- } \\
\text { damaging:0.935 }\end{array}$ \\
\hline rs139926880 & $A>C$ & $C=0 / A=8600$ & $C=1 / A=4405$ & missense & $\begin{array}{l}\text { probably- } \\
\text { damaging:0.992 }\end{array}$ \\
\hline rs139092674 & $C>T$ & $\mathrm{~T}=1 / \mathrm{C}=8599$ & $\mathrm{~T}=0 / \mathrm{C}=4406$ & missense & $\begin{array}{l}\text { probably- } \\
\text { damaging:0.966 }\end{array}$ \\
\hline rs373847134 & $\mathrm{T}>\mathrm{A}$ & $A=1 / T=8599$ & $A=0 / T=4406$ & missense & $\begin{array}{l}\text { probably- } \\
\text { damaging:0.993 }\end{array}$ \\
\hline rs12329760 & $C>T$ & $\mathrm{~T}=1860 / \mathrm{C}=6740$ & $\mathrm{~T}=1279 / \mathrm{C}=3127$ & missense & $\begin{array}{l}\text { probably- } \\
\text { damaging:0.999 }\end{array}$ \\
\hline rs 147711290 & $A>T$ & $T=0 / A=8600$ & $T=31 / A=4375$ & missense & $\begin{array}{l}\text { probably- } \\
\text { damaging:0.999 }\end{array}$ \\
\hline rs114363287 & $C>T$ & $\mathrm{~T}=1 / \mathrm{C}=8599$ & $\mathrm{~T}=29 / \mathrm{C}=4377$ & missense & $\begin{array}{l}\text { possibly- } \\
\text { damaging:0.641 }\end{array}$ \\
\hline rs377060358 & $\mathrm{G}>\mathrm{A}$ & $A=2 / G=8598$ & $A=0 / G=4406$ & missense & $\begin{array}{l}\text { possibly- } \\
\text { damaging:0.673 }\end{array}$ \\
\hline rs138651919 & $G>A$ & $A=5 / G=8595$ & $A=0 / G=4406$ & missense & $\begin{array}{l}\text { probably- } \\
\text { damaging:0.998 }\end{array}$ \\
\hline rs371006143 & $\mathrm{G}>\mathrm{T}$ & $T=1 / G=8599$ & $\mathrm{~T}=0 / \mathrm{G}=4406$ & missense & $\begin{array}{l}\text { probably- } \\
\text { damaging:0.968 }\end{array}$ \\
\hline$\underline{\text { rs } 375223866}$ & $C>T$ & $\mathrm{~T}=2 / \mathrm{C}=8598$ & $\mathrm{~T}=0 / \mathrm{C}=4406$ & missense & $\begin{array}{l}\text { probably- } \\
\text { damaging:0.994 }\end{array}$ \\
\hline rs386416 & $\mathrm{G}>\mathrm{C}$ & $C=6201 / G=2399$ & $\mathrm{C}=2472 / \mathrm{G}=1932$ & intron & unknown \\
\hline rs 422471 & $C>T$ & $\mathrm{~T}=6204 / \mathrm{C}=2396$ & $\mathrm{~T}=2475 / \mathrm{C}=1931$ & intron & unknown \\
\hline rs17854725 & $A>G$ & $\mathrm{G}=4660 / \mathrm{A}=3900$ & $G=1714 / A=2650$ & $\begin{array}{l}\text { Coding- } \\
\text { synomous }\end{array}$ & unknown \\
\hline
\end{tabular}




\section{Pathway Analysis of Prostate Cancer}

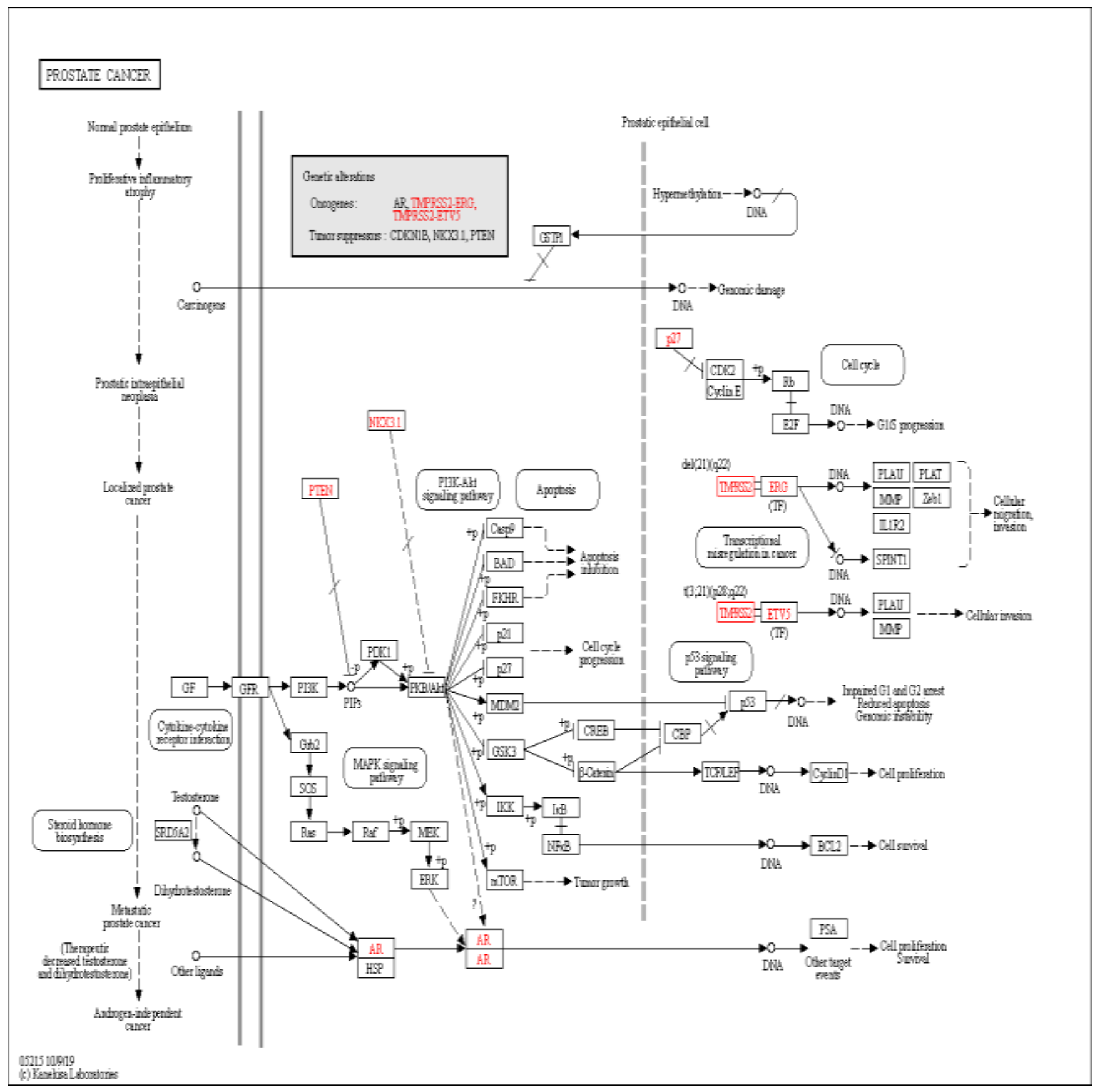

Figure 2. KEGG pathway analysis was used to identify prostate cancer mechanisms for TMPRSS2 in the form of a schematic diagram. It shows the metabolic and signaling pathways, pathways involved in different cellular processes and structures, and perturbed pathways linked to prostate cancer. The important role of the AR gene was shown together with other oncogenes and tumor suppressor genes (highlighted in red) to indicate the connection and function in the prostate cancer pathway. 


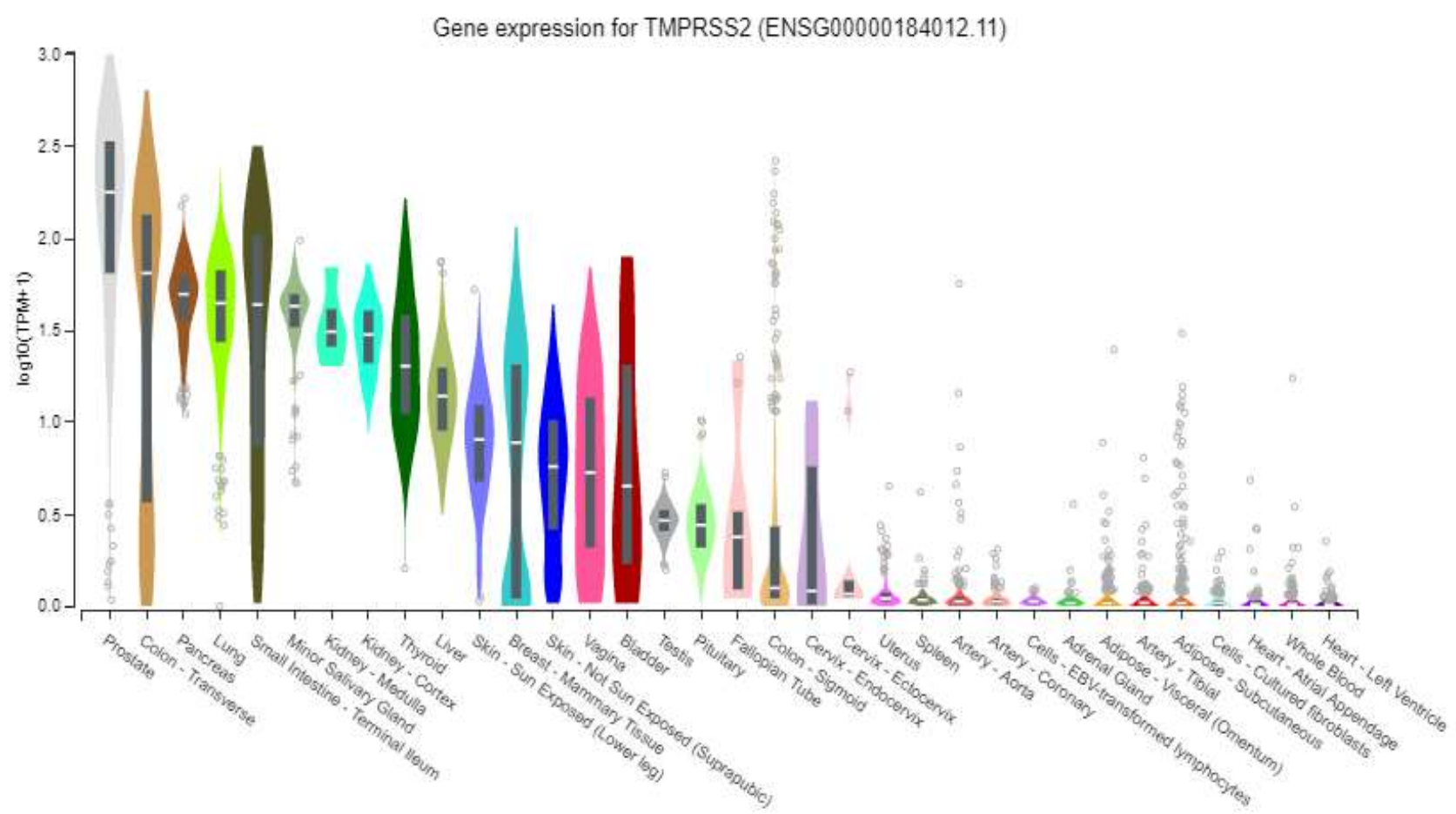

Figure 3. This figure shows differential expression analysis for the TMPRSS2 gene in a logarithmic scale. Values of gene expression were indicated in transcripts per million. The points displayed as outliers shows that they are below or above 1.5 times the interquartile range.

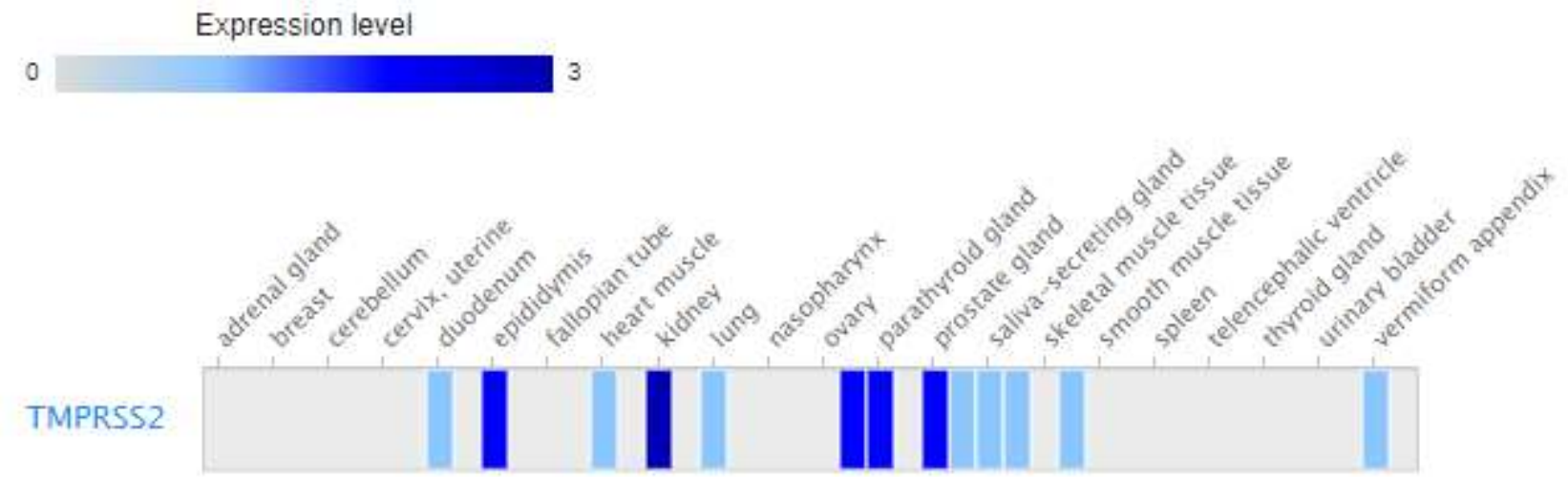

Figure 4. Expression level analysis of TMPRSS2 was found by Expression Atlas.

Table 2. Reported diseases and TMPRSS2 gene associations were indicated with Z score and confidence score obtained from the DISEASES database. Prostate cancer has the highest Z score followed by COVID-19.

\begin{tabular}{|c|c|c|}
\hline Name & Z Score & Confidence \\
\hline Prostate cancer & 7.0 & 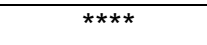 \\
\hline COVID-19 & 6.3 & $\star * \star \star *$ \\
\hline Carcinoma & 5.2 & *** \\
\hline Breast Cancer & 4.5 & *** \\
\hline Middle East Respitatory Syndrome & 4.4 & *** \\
\hline Severe Acute Respiratory Syndrome & 4.4 & *** \\
\hline Lung Cancer & 4.3 & *** \\
\hline Sarcoma & 4.3 & *** \\
\hline Leukemia & 4.2 & *** \\
\hline Influenza & 4.2 & $\star * *$ \\
\hline
\end{tabular}

$Z$ score indicates the density of people of the same age, sex, and genetic background.

Confidence score indicates a comparable value for different types and sources of evidence. 


\section{DISCUSSION}

Recently, studies have demonstrated that prostate cancer is linked with COVID-19 [33]. Especially, based on a study, prostate cancer patients who received androgen therapy had a lower risk for SARS-COV2 infection compared to patients who did not (receive androgen deprivation therapy) [20]. The comprehensive mechanism of prostate cancer treatment is also important in understanding the protective effects against COVID-19 [34].

In this study, we investigated the link between prostate cancer and COVID-19, contributing to elucidate the relationship between TMPRSS2 and ACE2. We found that TMPRSS2 interacted with ACE2, ACE, AGT, PDE9A, SLC44A4, RASEF, TRPM4, SLC10A2, SLC37A1, and CAT genes illustrated in Figure 1. Our study has shown that SLC44A, PDE9A, SLC37A1 have a relationship with ACE2, and they are co-expressed with TMPRSS2. That may be because of their genetically similar expression patterns. The PDE9A gene is phosphodiesterase specific [19], which has a special role in signal transduction, and it regulates the intracellular concentration of cyclic nucleotides. As stated in a study, PDE9A is used as a marker for detecting, determining, diagnosing prostate cancer [35,36]. SLC37A1 is a solute carrier protein that it has pointed out as a potential candidate for the carrying of $G 3 P$ in the endoplasmic reticulum and/or mitochondria [37]. Coexpression of genes represents a relationship in transcription levels, and co-expression can be used to understand the connection of proteins, metabolites, or a combination of transcripts, with other genes in the biological process $[38,39]$. This study has revealed that TMPRSS2 is linked with ACE2 and both two genes have a co-expression profile with SLC37A1, PDE9A, and SLC44A genes. There is currently no study in the literature that summarizes this situation. In the future perhaps this study will contribute to why COVID-19 is seen more in men over the age of 65 and defining gene co-expression networks could help to understand the mechanism of COVID-19.

SNPs are one of the most important types of genetic variations in the human genome and SNPs in genes that regulate DNA mismatch repair, cell cycle regulation, metabolism and immunity are related to genetic susceptibility to cancer and alterations in gene expression and their consequence on cancer susceptibility differ depending on the location of the SNP [40]. Hariom and his colleagues have thought that investigating the genetic variants and expression of ACE2 and TMPRSS2 genes, in a population can support the genetic marker for susceptibility or resistance against the coronavirus infection, which could be advantageous for defining the susceptible population groups for targeted interventions [41]. Thus; we aimed to find variants in the TMPRSS2 gene in this study and we discovered 209 variants in the TMPRSS2 gene, and 110 variants represent EA populations and 99 of them represent AA populations. Moreover, we found 23 suspected missense and 3 unknown variants indicated in Table 1. We assumed that these mutations can be significant for pulmonary expression of the TMPRSS2. We are the first group who is defining variants on TMPRSS2 gene. We have thought that this information can contribute to other studies.

ACE2 gene encodes a cell receptor, and it permits the viral S protein to attach to the cell. On the other hand, the TMPRSS2 gene encodes a serine protease which locates on the cell membrane as a fusion protein and facilitates the host cell membrane and viral membrane to fuse during the attachment with spike protein [44]. Latest studies have highlighted that roles of ACE2 and TMPRSS2 genes have been identified in SARSCoV and MERS-CoV infections [42-44]. Therefore, describing the molecular mechanisms regulating the expression of TMPRSS2 and ACE2 probably clarifies the variation in SARS-CoV-2 infection-related death in men [15]. A study has indicated that finding details of ACE2-Spike protein and TMPRSS2-Spike protein interactions might further highlight future research on COVID-19 [45]. We evaluated the TMPRSS2 mechanism through the prostate cancer pathway and interpreted its relationship with the ACE2 gene (Figure 2). According to the results, the expression level of TMPRSS2 is very high in the prostate, colon, lung, kidney, and saliva secreting glands (Figure 3, Figure 4). Therefore, we have seen that AR is a marker for the phenotype of prostate cancer cells. Generally, AR is activated by an androgen ligand and it is a DNA-binding transcription factor, and it has a critical role in the development of male sexual phenotype [46]. AR is abundantly expressed in the lungs and high expression of $A R$ is seen in males compared with females. According to the results, we assumed that our study supports significant information regarding the probable connection between TMPRSS2 and ACE2 co-expression and gender differences in COVID-19. We predict special information concerning TMPRSS2 and ACE2 expression in patients experiencing various clinical manifestations might propose new directions for present and future research on COVID-19.

In this study, when the mechanism of SARS-CoV-2 was analyzed, we have seen that ACE2 and TMPRSS2 use the same pathway to attach to human cells. The main infection route of the SARS-CoV, MERS-CoV, and SARS-CoV-2 is that air passes through the upper respiratory tract $[47,48]$. The tissue of the upper respiratory tract can express both ACE2 and TMPRSS2. Thus, it can be a potential target for the entry 
of these viruses into human cells. COVID-19 is a disease that has never been seen in humans before, but there are no validated drugs at this time, and the most significant public health remedy will be an efficient vaccine. The male predisposition of SARS-CoV-2 and the androgen-dependent expression of TMPRSS2 suggest that, as with SARS-CoV and influenza virus, targeting TMPRSS2 may be a novel choice for treating COVID-19 [9, 49]. Male pneumocytes $\mathrm{I} / \mathrm{II}$ had higher TMPRSS2 and ACE2 co-expression than female pneumocytes I/II, despite no differences between men and women in TMPRSS2 distribution in human lung tissue. That insight highlights a significant problem with the COVID-19 pandemic's epidemiology of sex differences [50, 51].

In conclusion, TMPRSS2, ACE2, and AR connections explain why the high expression of the $A R$ gene is present in the male lung, and it can contribute to solving a part of the mechanism of SARS-CoV-2. Detailed information on TMPRSS2 and ACE2 expression in patients with various clinical indications, we assume, may point to new possibilities for current and future COVID-19 study. This study provides important knowledge to the scientific world. On the other hand, the biggest limitation is that this study can only be evaluated as a prediction study. It should be supported by the laboratory work and will also shed a light on these studies.

Funding: Not applicable. The study is self-funded by the authors.

Conflict of interest: The authors declare that they have no conflict of interest.

\section{REFERENCES}

1. Jemal A, Center MM, DeSantis C, Ward EM. Global patterns of cancer incidence and mortality rates and trends. Cancer Epidemiol. Biomarkers Prev. 2010 Aug;19(8):1893-907.

2. Mattiuzzi C, Lippi G. Current Cancer Epidemiology. J Epidemiol Glob Health. 2019 Dec;9(4):217-22

3. Bray F, Ferlay J,Soerjomataram I, Siegel RL, Torre LA, Jemal ACA. Global cancer statistics 2018: GLOBOCAN estimates of incidence and mortality worldwide for 36 cancers in 185 countries. CA Cancer J Clin. 2018 Nov;68(6):394-424.

4. Bostwick DG, Burke HB, Djakiew D, Euling S, Ho SM, Landolph J et al. Human prostate cancer risk factors. Cancer. 2004 Nov 15;101(10 Suppl):2371-490.

5. Pienta KJ, Esper PS. Risk factors for prostate cancer. Ann Intern Med. 1993 May 15;118(10):793-803.

6. Sungnak W, Huang N, Becavin C, Berg M, Queen R, Litvinukova M, et al. SARS-CoV-2 entry factors are highly expressed in nasal epithelial cells together with innate immune genes. Nature Medicine. 2020 May;26(5):681-7.

7. Lin B, Ferguson C, White JT, Wang S, Vessela R, True LD, et al. Prostate-localized and androgen-regulated expression of the membrane bound serine protease TMPRSS2. Cancer Res. 1999 Sep 1;59(17):4180-4.

8. Lucas JM, True L, Hawley S, Matsumura M, Morrissey C, Vessella R, et al. The androgen-regulated type II serine protease TMPRSS2 is differentially expressed and mislocalized in prostate adenocarcinoma. J Pathol. 2008 Jun;215(2):118-25.

9. Mollica V, Rizzo A, Massari F. The pivotal role of TMPRSS2 in coronavirus disease 2019 and prostate cancer. Future Oncol. 2020 Sep;16(27):2029-2033.

10. Stephan C, Rittenhouse H, Hu X, Cammann H, Jung K. Prostate-Specific Antigen (PSA) Screening and New Biomarkers for Prostate Cancer (PCa). EJIFCC. 2014 Apr 28;25(1):55-78.

11. Tomlins SA, Palanisamy N, Siddiqui J, Chinnaiyan AM, Kunju LP. Antibody-based detection of ERG rearrangements in prostate core biopsies, including diagnostically challenging cases: ERG staining in prostate core biopsies. Arch Pathol Lab Med. 2012 Aug;136(8):935-46.

12. Gasi Tandefelt D, Boormans J, Hermans K, Trapman J. ETS fusion genes in prostate cancer. Endocr Relat Cancer. 2014 May 6;21(3):R143-52.

13. Zhou F, Gao S, Han D, Han W, Chen S. TMPRSS2-ERG activates NO-cGMP signaling in prostate cancer cells. Oncogene. 2019 May;38(22):4397-4411.

14. Cheng J, Zhou J, Fu S, Fu J, Zhou B, Chen H, Fu J, Wei C. Prostate adenocarcinoma and COVID-19: The possible impacts of TMPRSS2 expressions in susceptibility to SARS-CoV-2. J Cell Mol Med. 2021 Apr;25(8):4157-4165.

15. University of Tokyo. Identification of an existing Japanese pancreatitis drug, nafamostat, which is expected to prevent the transmission of new coronavirus infection (COVID-19). www.utokyo.ac.jp/focus/en/articles/z0508_00083.html.

16. Lambertz RLO, Gerhauser I, Nehlmeier I, Leist SR, Kollmus H, Pöhlmann S, et al. Journal of General Virology.Tmprss2 knock-out mice are resistant to H10 influenza A virus pathogenesis. J Gen Virol. 2019 Jul;100(7):1073-1078.

17. Weekly epidemiological update on COVID-19 - 27 April 2021. https://www.who.int/publications/m/item/weeklyepidemiological-update-on-covid-19---27-april-2021. Accessed April 28, 2021. 
18. Montopoli M, Zumerle S, Vettor R, Rugge M, Zorzi M, Catapano CV, et al. Androgendeprivation therapies for prostate cancer and risk of infection by SARS-CoV-2: a population-based study $(n=4532)$. Ann Oncol. 2020 Aug;31(8):1040-5

19. Stopsack KH, Mucci LA, Antonarakis ES, Nelson PS, Kantoff PW. TMPRSS2 and COVID-19: serendipity or opportunity for intervention. Cancer Discov. 2020 Jun;10(6):779-82.

20. OMIM-Online Mendelian Inheritance in Man [accessed 2020 Dec 01]. htpps://omim.org/.

21. National Center of Biotechnology Information. https://ncbi.nlm.nih.gov/ [accessed 2020 Dec 01]

22. Home-SNP-NCBI. https://ncbi.nlm.nih.gov/snp [accessed 2020 Dec 01]

23. ExPASy: SIB Bioinformatics Resource Portal-Home- [accessed 2020 Dec 01] https://expasy.org/

24. STRING: functional protein association networks [accessed Apr. 09, 2020]. https://string-db.org/.

25. Exome Variant Server [accessed Dec. 01, 2020]. https://evs.gs.washington.edu/EVS/

26. PROVEAN Home [accessed Dec. 02, 2020]. http://provean.jcvi.org/index.php.

27. PolyPhen-2: prediction of functional effects of human nsSNPs. http://genetics.bwh.harvard.edu/pph2/

28. Robinson JT, Thorvaldsdóttir H, Winckler W, Guttman M, Lander ES, Getz G, et al. Integrative genomics viewer. Nat Biotechnol. 2011 Jan;29(1):24-6.

29. Ensembl genome browser 99 [accessed 2020 Dec 01]. https://www.ensembl.org/index.html

30. GTEx Portal [accessed 2020 Dec 01]. https://gtexportal.org/home/

31. KEGG PATHWAY Database [accessed 2020 Dec 01]. https://www.kegg.jp/kegg/pathway.html

32. DISEASES- Search [accessed 2020 Nov. 12]. https://diseases.jensenlab.org/Search

33. Kalkanli Tas S, Kirkik D, Işik ME, Kalkanli N, Uzunoglu AS, Uzunoglu MS et al. Role of ACE2 Gene Expression in Renin Angiotensin System and Its Importance in Covid-19: In Silico Approach. Brazilian Archives of Biology and Technology. 2020; 63:2020200304

34. Fisher DA, Smith JF, Pillar JS, Denis SH, Cheng JB. Isolation and characterization of PDE9A, a novel human cGMPspecific phosphodiesterase. J. Biol. Chem. 1998 Jun 19;273(25):15559-64.

35. Ghashghaei M, Niazi TM, Mahecha AA, Klein OK, Greenwood CMT, Basik M, et al. Identification of a Radiosensitivity Molecular Signature Induced by Enzalutamide in Hormone-sensitive and Hormone-resistant Prostate Cancer Cell. Sci Rep. 2019 Jun 20;9(1):8838.

36. Henderson DJP, Houslay MD, Bangma CH, Hoffman R. Creating a potential diagnostic for prostate cancer risk stratification (InformMDx ${ }^{\mathrm{TM}}$ ) by translating novel scientific discoveries concerning CAMP degrading phosphodiesterase-4D7 (PDE4D7). Clin Sci (Lond). 2019 Jan 25;133(2):269-286.

37. Lacopetta D, Lappano R, Cappello AR, Madeo M, Francesco EM, Santoro A, et al. SLC37A1 Gene expression is up-regulated by epidermal growth factor in breast cancer cells. Breast Cancer Res Treat. 2010 Aug;122(3):755-64.

38. Farber CR, Mesner LD. A Systems-Level Understanding of Cardiovascular Disease through Networks. Mesner, in Translational Cardiometabolic Genomic Medicine, 2016; 59-81. doi:10.1016/b978-0-12-799961-6.00003-2

39. Kabir H, Patrick R, Ho JWK, O'connor MD. Identification of active signaling pathways by integrating gene expression and protein interaction data. BMC Syst Biol. 2018 Dec 31;12(Suppl 9):120.

40. Deng N, Zhou H, Fan H, Yuan Y. Single nucleotide polymorphisms and cancer susceptibility. Oncotarget. 2017: 15; 8(66): 110635-110649.

41. Singh $H$, Choudhari $R$, Nema V, Khan AA. ACE2 and TMPRSS2 polymorphisms in various diseases with special reference to its impact on COVID-19 disease. Microb Pathog. 2021; 150: 104621.

42. Hoffmann M, Kleine WH, Schroeder S, Krüger N, Herrler T, Erichsen S. et al. SARSCoV-2 Cell Entry Depends on ACE2 and TMPRSS2 and Is Blocked by a Clinically Proven Protease Inhibitor. Cell. 2020 Apr 16;181(2):271-280.e8.

43. Bertram S, Dijkman R, Habjan M, Gierer S, Glowacka I, Welsch K. et al. TMPRSS2 activates the human coronavirus $229 \mathrm{E}$ for cathepsin-independent host cell entry and is expressed in viral target cells in the respiratory epithelium. $J$ Virol. 2013 Jun;87(11):6150-60.

44. Shulla A, Heald ST, Subramanya G, Zhao J, Perlman S, Gallagher TA. Transmembrane serine protease is linked to the severe acute respiratory syndrome coronavirus receptor and activates virus entry. J Virol. 2011 Jan;85(2):87382.

45. Senapati S, Banerjee P, Bhagavatula S, Kushwaha PP, Kumar S. Contributions of human ACE2 and TMPRSS2 in determining host-pathogen interaction of COVID-19. J Genet. 2021;100(1):12.

46. Shirato K, Kawase M, Matsuyama S. Middle East respiratory syndrome coronavirus infection mediated by the transmembrane serine protease TMPRSS2. J Virol. 2013 Dec;87(23):12552-61.

47. Mooradian AD, Morley JE, Korenman SG. Biological actions of androgens. Endocr Rev. 1987 Feb;8(1):1-28.

48. Shen LW, Mao HJ, Wu YL, Tanaka Y, Zhang W. TMPRSS2: A potential target for treatment of influenza virus and coronavirus infections. Biochimie. 2017 Nov;142:1-10. 
49. Lukassen S, Chua RL, Trefzer T, Kahn NC, Schneider MA, Muley T. et al. SARSCoV-2 receptor ACE2 and TMPRSS2 are primarily expressed in bronchial transient secretory cells. EMBO J. 2020 May 18;39(10):e105114.

50. Deng Q, Rasool R, Russel RM, Natesan R, Asangani I. Targeting androgen regulation of TMPRSS2 and ACE2 as a therapeutic strategy to combat COVID-19. IScience 2021 Mar 19;24(3):102254.

51. Rizzo A, Mollica V, Massari F. Re: Hanbing Song, Bobak Seddighzadeh, Matthew R. Cooperberg, Franklin W. Huang. Expression of ACE2 and TMPRSS2, the SARS-CoV-2 Receptor and Co-Receptor, in Prostate Epithelial Cells. Eur Urol. Eur Urol. 2020 Nov;78(5):e205-e206.

2021 by the authors. Submitted for possible open access publication under the terms and conditions of the Creative Commons Attribution (CC BY NC) license (https://creativecommons.org/licenses/by-nc/4.0/). 